\title{
Sistem Monitoring pH dan Volume Biogas Digester Dua Tahap menggunakan Mikrokontroler
}

\author{
SRI UTAMI, PURWINDA IRIANI, YANTI SUPRIANTI \\ Jurusan Teknik Konversi Energi Politeknik Negeri Bandung \\ Email: utamiwu@yahoo.com
}

Received 27 September 2018 | Revised 23 Oktober 2018 | Accepted 7 Januari 2019

\begin{abstract}
ABSTRAK
Biogas merupakan salah satu sumber energi terbarukan yang murah dan berkategori non-polusi. Kebutuhan untuk memonitor serta mengontrol plant biogas bertambah seiring kebutuhan mengoptimalkan stabilitas proses untuk mendapatkan performansi yang tinggi. Monitoring biogas dapat memberikan gambaran keseluruhan proses pembangkitan biogas dan digunakan untuk memprediksi proses fermentasi yang berlangsung. Selain itu, dapat pula meminimalkan gagalnya proses fermentasi dan menghasilkan biogas secara optimal. Dalam penelitian ini proses monitoring dilakukan pada digester dua tahap berbahan dasar ampas tahu dan difokuskan pada $\mathrm{pH}$ dan volume biogas yang dihasilkan menggunakan dfrobot sku Sen0160 dan YF-S201 serta solenoid valve sebagai aktuatornya. Hasil penelitian menunjukkan bahwa set point pH 5.3 pada digester asetogenesis dapat dicapai pada hari ke enam untuk tiga percobaan. Dalam digester metanogenesis nilai $\mathrm{pH}$ dapat dijaga pada $\mathrm{pH} 7 \pm 0.3$. Jumlah volume biogas tertinggi yang dihasilkan sebesar 97.2 L .
\end{abstract}

Kata kunci: digester dua tahap, fermentasi, asetogenesis, metanogenesis

\begin{abstract}
Biogas is one of an inexpensive and non-pollution renewable energy source. $A$ requirement for optimization and stabilization of biogas plant affected on the need of monitor and control system in the plant. Biogas monitoring system represents a process in biogas generation and has the ability to predict fermentation. In addition, the system built can be used to control the fermentation process and to minimize the failure of the process. This means the process will produce biogas optimally. In this research, the monitoring system was used on two stages digester using tofu as raw material. $\mathrm{pH}$ and biogas volume produced are two focuses in this study using SKU Sen0160 dan YF-S201 as sensors and solenoid valve as an actuator. For three experiments data show, set point for $\mathrm{pH}$ (5.3) is achieved at day sixth for acetogenesis digester. For methanogenesis, $\mathrm{pH}$ can be maintained at $7 \pm 0.3$. The highest volume of biogas produced was 97.2 L.
\end{abstract}

Keywords: two stages digester, fermentation, acetogenesis, methanogenesis digester 


\section{PENDAHULUAN}

Biogas merupakan suatu teknologi yang memanfaatkan bahan baku organik, seperti kotoran hewan, kotoran manusia, sampah organik, yang melewati proses pembusukan (fermentasi) dari material organik kompleks tersebut menjadi materi yang lebih sederhana. Proses dilakukan secara anaerob (tanpa oksigen) dan memerlukan suatu mikroba, bakteri atau ragi untuk membantu.

Terdapat beberapa jenis digester untuk pembentukan biogas diantaranya adalah biogas satu tahap dan biogas dua tahap. Dalam digester satu tahap semua tahapan dalam pembentukan biogas (tahap pembentukan asam asetat, biasa disebut sebagai proses asetogenesis, dan perubahannya menjadi metan, disebut proses metanogenesis) terjadi dalam satu digester. Sedangkan dalam digester dua tahap terdapat pemisahan dalam tahapan produksi asam asetat dan gas metan. Pemisahan tahapan ini dimaksudkan untuk memaksimalkan proses penguraian mikroba pada pembentukan asam asetat dan gas metan. Dengan pemisahan proses ini produksi biogas dapat ditingkatkan.

Untuk menghasilkan energi, proses fermentasi biogas berlangsung selama beberapa minggu. Dalam proses ini monitoring dan pengendalian mempunyai peranan penting untuk dapat mengerti proses yang sedang terjadi dalam plant dan membantu untuk mencapai proses yang stabil. Dalam beberapa kasus, populasi mikroorganisme yang tidak terkendali dapat mengakibatkan gagalnya proses pembentukan biogas yang dapat berimplikasi pada konsekuensi finansial (Dedgaonkar dkk, 2016). Untuk mengatasi hal tersebut diperlukan sebuah komponen yang tersusun dalam sistem dan dapat digunakan untuk melakukan pengukuran dan pengambilan keputusan dalam plant biogas.

Pengembangan teknologi mikrokontroller dan semikonduktor mengalami peningkatan seiring dengan perkembangan kebutuhan akan pengendalian dan monitoring sistem. Proses pengendalian dan monitoring ini berlaku pula dalam renewable energy. Beberapa penelitian mengenai penggunaan mikrokontroller dalam bidang energi terbarukan seperti untuk kontrol pada pembangkitan energi surya seperti yang dilakukan oleh Utami (Utami dkk, 2018), untuk sistem akuisisi data pada sistem energi hybrid (Demirtas dkk, 2008), sistem akuisisi data pada wind turbine (Maheshwari dkk, 2014) dan sistem managemen energi untuk solar dan biomassa (Karoly \& Dumitru, 2014).

Beberapa penelitian telah dilakukan terkait dengan monitoring plant biogas. Seperti penelitian yang dilakukan oleh Sunil dkk (Sunil dkk, 2013) telah melakukan monitoring suhu dan tekanan digester berbahan dasar sampah rumah tangga serta sampah sisa makanan. Dalam penelitian tersebut digunakan PIC mikrokontroler serta data ditampilkan menggunakan LCD. Penelitian lain yang dilakukan oleh Ahmed dkk (Ahmed dkk, 2015) yang menggunakan sistem monitoring biogas untuk meningkatkan efisiensi digester yang bertujuan untuk meningkatkan produksi biogas.

Terdapat beberapa parameter yang perlu dipantau dalam plant biogas diantaranya adalah $\mathrm{pH}$, temperatur, tekanan, dan level. Dari beberapa faktor yang mempengaruhi nilai efisiensi digester dan berpengaruh pada produksi biogas dan sangat penting untuk dipantau adalah nilai $\mathrm{pH}$. Hal ini disebabkan oleh proses cerna anaerobik subtrat organik membutuhkan penggabungan aktivitas beberapa kelompok mikroorganisme yang sensitif terhadap nilai perubahan $\mathrm{pH}$. Untuk proses asetogenesis dapat bereaksi ketika nilai $\mathrm{pH} \leq 6$. Faktor yang mempengaruhi perubahan nilai pH pada tahap asetogenesis adalah produk yang dihasilkan berupa asam asetat dan senyawa asam yang lain yang akan berpengaruh terhadap perubahan $\mathrm{pH}$ menjadi asam. Jika didapatkan nilai $\mathrm{pH}$ yang asam pada proses asetogenesis maka proses 
berikutnya, yaitu metanogenesis, akan bekerja kurang optimal mengingat pada proses metanogenesis memerlukan kondisi $\mathrm{pH}=7$ (Iriani dkk, 2018). Efisiensi sistem dapat dicapai salah satunya adalah dengan pengendalian $\mathrm{pH}$ pada kisaran nilai yang tepat untuk memastikan produksi serta mencegahnya dari potensi kegagalan (Labatut, 2009).

Penelitian yang telah dilakukan menunjukkan belum adanya penelitian monitoring dan pengendalian pada digester dua tahap. Ide dasar penelitian ini adalah melakukan proses monitor dan kontrol $\mathrm{pH}$ dan volume biogas yang dihasilkan dengan memisahkan proses asetogenesis dan metanogenesis untuk menjaga stabilitas proses pembentukan biogas menggunakan bahan dasar ampas tahu.

\subsection{Biogas}

Biogas, dikenal juga sebagai gas bio, merupakan salah satu alternatif energi yang dihasilkan dari beberapa jenis bahan tidak terpakai atau bahan sisa seperti kotoran ternak, sampah, eceng gondok, limbah tahu serta bahan lainnya. Biogas dibentuk dari perombakan bahan organik yang dibantu oleh mikroba pada kondisi tanpa oksigen. Proses tersebut dikenal dengan anaerob (Muljatiningrum \& Sukmana, 2011).

Salah satu kandungan biogas adalah gas metan $\left(\mathrm{CH}_{4}\right)$ dengan persentase yang tinggi sehingga dapat digunakan sebagai bahan bakar terbarukan (Juangga, 2007). Bahan bakar ini dapat digunakan untuk kendaraan atau untuk menghasilkan panas atau listrik untuk penggunaan secara lokal atau didistribusikan melaui grid. Sehingga dapat dikatakan bahwa biogas merupakan sumber utama energi yang dapat diandalkan di masa mendatang.

\subsection{Digester Dua Tahap}

Digester dua tahap, atau yang diketahui juga sebagai digester dua tahap, merupakan suatu suatu plant biogas yang menggunakan dua buah digester. Dalam digester pertama terjadi reaksi hydrolysis, acidogenesis, dan acetogenesis. Sedangkan dalam digester kedua terjadi reakis yang bernama metanogenesis. Terdapat perbedaan kondisi $\mathrm{pH}$ terbaik pada tahap asetogenesis dan metanogenesis. Nilai pH yang tidak optimum dapat mempengaruhi tingkat pertumbuhan organisme pada tahap tersebut. Sehingga pemakaian dua buah reaktor ini memungkinkan lebih unggul dalam pembuatan biogas. Digester dengan dua reaktor ini seperti Gambar 1.

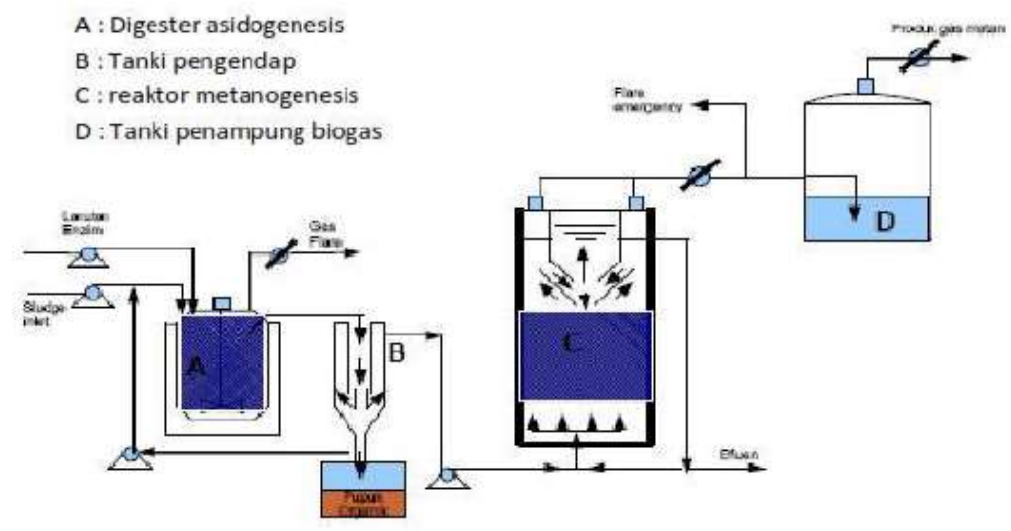

Gambar 1. Digester dengan Sistem Dua Tahap (Soetopo dkk, 2010) 


\subsection{Sistem Monitoring dan Kontrol}

Prinsip utama dari sistem monitoring ini sebagaimana yang telah disebutkan oleh Boe (Boe, 2006) diperoleh dari pembacaan, penyimpan, dan pengolahan data serta display data seperti yang diilustrasikan oleh Gambar 2.

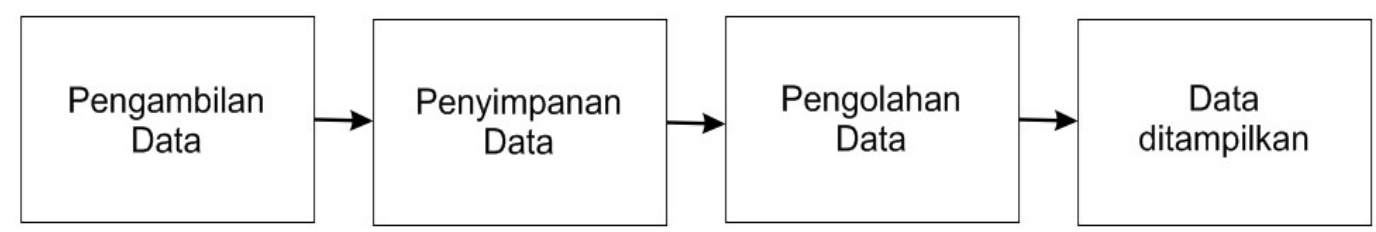

\section{Gambar 2. Proses Pemantauan Di Dalam Sistem}

Sistem monitoring dalam proses produksi biogas mempunyai beberapa tujuan yang antara lain untuk mengidentifikasi jika terdapat potensi ketidakstabilan proses fermentasi anaerobik sehingga dapat dicegah jika terjadi kegagalan sistem. Dengan adanya data pada proses monitoring maka pada proses pembentukan biogas dapat dikalkulasi jumlah volume gas yang dihasilkan, mendeteksi jenis gas yang dikeluarkan, memberikan pengukuran yang lebih akurat untuk gas yang masih dalam proses fermentasi. Dengan adanya keseluruhan proses tersebut, sistem dapat dikatakan sebagai plant biogas pintar.

Sistem kontrol pada $\mathrm{pH}$ dan level digester dirancang untuk mengkondisikan $\mathrm{pH}$ serta level tetap berada pada set point yang ditentukan. Sistem ini berada pada digester asetogenesis (digester pertama dari sistem digester dua tahap) yang berfungsi untuk memisahkan dan menjaga kondisi kondisi $\mathrm{pH}$ sesuai dengan yang dibutuhkan pada proses metanogenesis (digester tahap ke dua).

\subsection{Sensor Keasaman (pH)}

Sensor $\mathrm{pH}$ digunakan untuk mengukur nilai keasaman (alkalinitas) suatu cairan yang mempunyai prinsip pada perbandingan antara potensial elektro kimia yang berada pada larutan dalam elektroda gelas dengan larutan di luar elektroda gelas. Interaksi antara lapisan gelembung kaca dengan ion hidrogen akan menyebabkan terjadinya perbedaan potensial elektrokimia yang diketahui juga sebagai potential of hidrogen. Elektroda pembanding dan elektroda gelas merupakan susunan satu kesatuan sebagaimana pada Gambar 3.

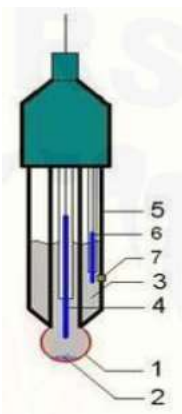

\section{Gambar 3 Elektroda pH Meter (Trisna, 2015)}

Pada penelitian ini digunakan sensor pH Sku Sen160 yang digunakan untuk mengukur derajat keasaman cairan uji sehingga dapat ditentukan apakah cairan tersebut normal, basa atau asam. Sensor ini berada dalam satu modul rangkaian yang mempunyai keluaran tegangan yang mempunyai nilai akurasi sebesar \pm 0.1 dan dapat mengukur nilai $\mathrm{pH} 0$ sampai dengan 14. 


\subsection{Sensor FlowmeterYF-S201}

Sensor ini merupakan sensor yang dapat digunakan untuk mengukur aliran fluida yang mempunyai komponen pendukung berupa badan katup plastik, rotor, sensor dengan prisnsip Hall Effect, serta terdapat inlet dan outlet. Perputaran roda terjadi ketika terjadi dorongan yang akan mengakibatkan kecepatannya sebanding dengan laju alirannya. Sensor menghasilkan pulsa sebagai representasi dari putaran yang diterimanya. Melalui penghitungan pulsa akan diiperoleh perhitungan aliran yang terjadi pada sensor. Pembacaan volume diperoleh dari Persamaan (1).

\section{Dimana:}

$$
V=Q \times T
$$

$\mathrm{V}=$ volume (liter)

$\mathrm{Q}=$ laju alir (liter/min)

$\mathrm{T}=$ waktu

Dalam penelitian ini, laju alir dikondisikan konstan dengan mengatur aliran gas menggunakan pompa vakum.

Dari Persamaan (1) diperoleh pembacaan pulsa, untuk selanjutnya didapatkan nilai Q dengan Persamaan (2).

$$
Q=\frac{F}{K}
$$

\section{Dimana:}

$\mathrm{F}=$ frekuensi $(\mathrm{Hz})$

$\mathrm{K}=$ konstanta $(7.5)$

Sehingga dari Persamaan (1) dan (2) didapatkan nilai volume biogas yang dihasilkan.

\section{METODOLOGI}

Seiring dengan semakin banyaknya plant biogas skala besar menjadikan kebutuhan akan sistem monitoring dan pengendalian juga meningkat (Angelidaki \& Ahring, 1997). Hal ini disebabkan dengan adanya monitoring sistem dimungkinkan untuk melakukan proses optimasi produk biogas yang dihasilkan melalui pemaksimalan proses dan meminimalkan losses yang disebabkan oleh kegagalan sistem (Batstone dkk, 2004). Menurut penelitian Switzenbaum (Switzenbaum dkk, 1990) salah satu cara mengoptimalkan proses anaerobik untuk memaksimalkan potensi pembentukan biogas adalah dengan melalui pengembangan strategi sistem monitor dan kontrol sistem yang lebih baik.

\subsection{Sistem yang Diusulkan}

Biodigester dua tahap yang digunakan dalam penelitian ini terdiri dari dua tabung asetogenesis yang digunakan untuk reaksi hidrolisis asetogenesis dan tabung metanogenesis yang berada pada tahap kedua. Konstruksi biodigester yang digunakan seperti diilustrasikan Gambar 4 yang terdiri dari digester satu yang merupakan digester asetogenesis dan digester kedua yang merupakan digester metanogenesis. Pada digester asetogenesis terdapat katup masukan yang digunakan untuk memberikan bahan baku limbah yang akan dipakai. Diantara digester asetogenesis dan digester metanogenesis terdapat valve yang akan terbuka bila nilai set point $\mathrm{pH}$ pada digester asetogenesis tercapai. Kondisi valve terbuka menyebabkan berpindahnya 
bahan baku dari asetogenesis menuju metanogenesis. Sehingga proses fermentasi kedua dapat dilakukan untuk dapat menghasilkan biogas.

Bahan baku yang digunakan merupakan limbah ampas tahu dan sebagai starter digunakan kotoran sapi. Volume limbah yang digunakan pada digester asetogenesis sebesar $80 \mathrm{~L}$ dan digester metanogenesis sebanyak $300 \mathrm{~L}$.

Sistem kontrol yang digunakan untuk digester dua tahap ini terdiri dari sensor $\mathrm{pH}$ pada digester asetogenesis dan metanogenesis serta sensor volume produksi biogas. Sensor pH ini menjadi input bagi mikrokontroler. Keluaran mikrokontroler ditampilkan pada LCD dan direpresentasikan oleh relay yang terkoneksi dengan solenoid valve. Untuk flowmeter terletak di keluaran digester metanogenesis.

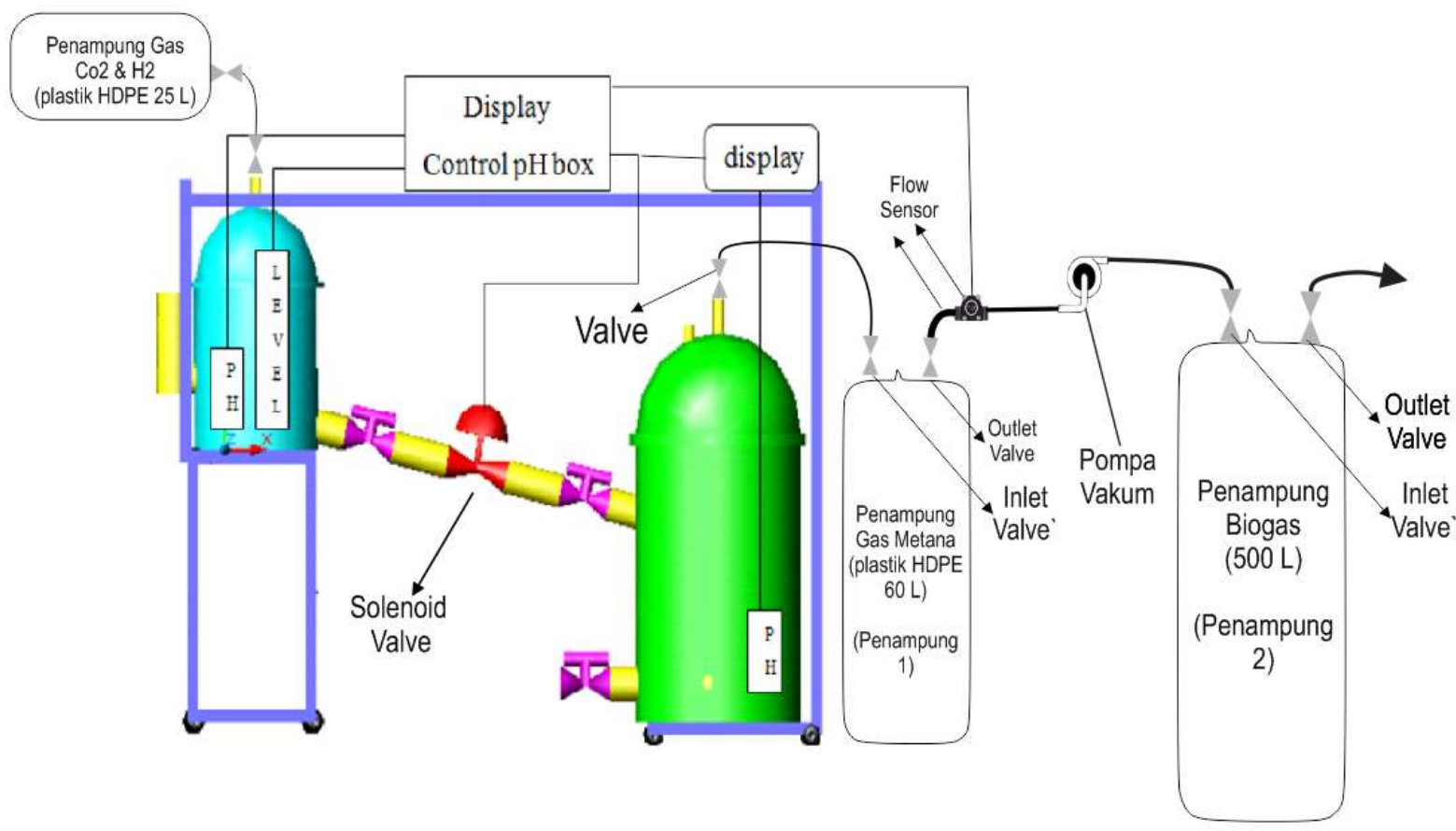

\section{Gambar 4. Desain Sistem Digester Dua Tahap}

Nilai pH pada proses asetogenesis dengan bahan baku ampas tahu berada pada kisaran 5.3 sedangkan pada proses metanogenesis berada pada \pm 7 yang dijadikan sebagai set point. Sebagai aktuator digunakan solenoid valve.

Sistem kontrol yang digunakan, Gambar 5, terdiri dari mikrokontroller sebagai kontrolernya dengan masukan berupa sensor pH dan flowmeter (blok A pada Gambar 5). Keluaran berupa data monitoring yang ditampilkan oleh LCD serta aktuator berupa solenoid valve yang akan mengalirkan limbah dari digester asetogenesis menuju digester metanogenesis. Dalam sistem ini juga terdapat data logger yang akan me-record data yang dihasilkan sehingga karakteristik sistem yang dipantau dapat diambil setiap saat serta digunakan untuk menentukan pola yang terjadi pada sistem. 


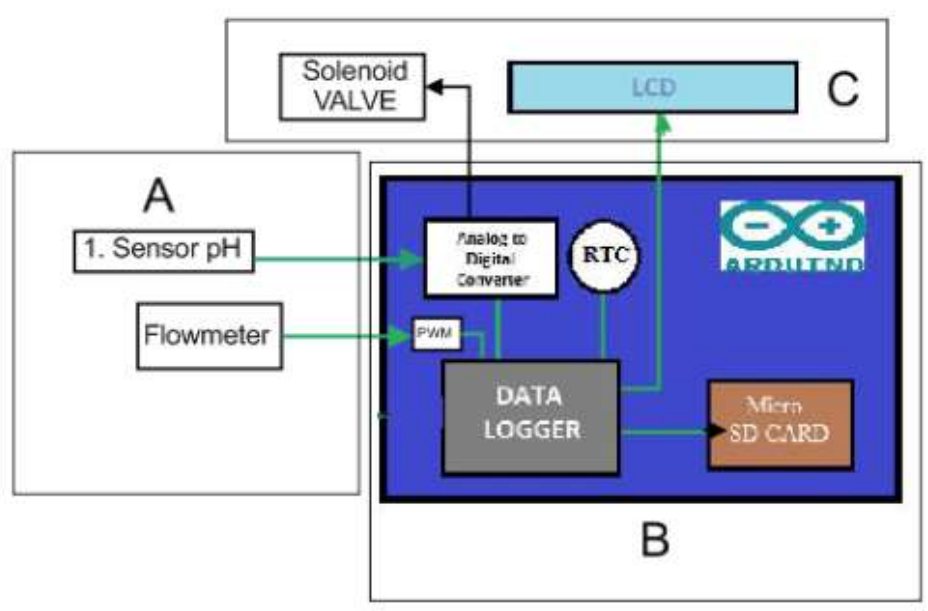

\section{Gambar 5. Desain Sistem Monitoring dan Kontrol Digester Dua Tahap}

\subsection{Realisasi Sistem}

Sistem yang dibangun menggunakan urutan pengerjaan sebagaimana yang ditunjukkan oleh Gambar 6.

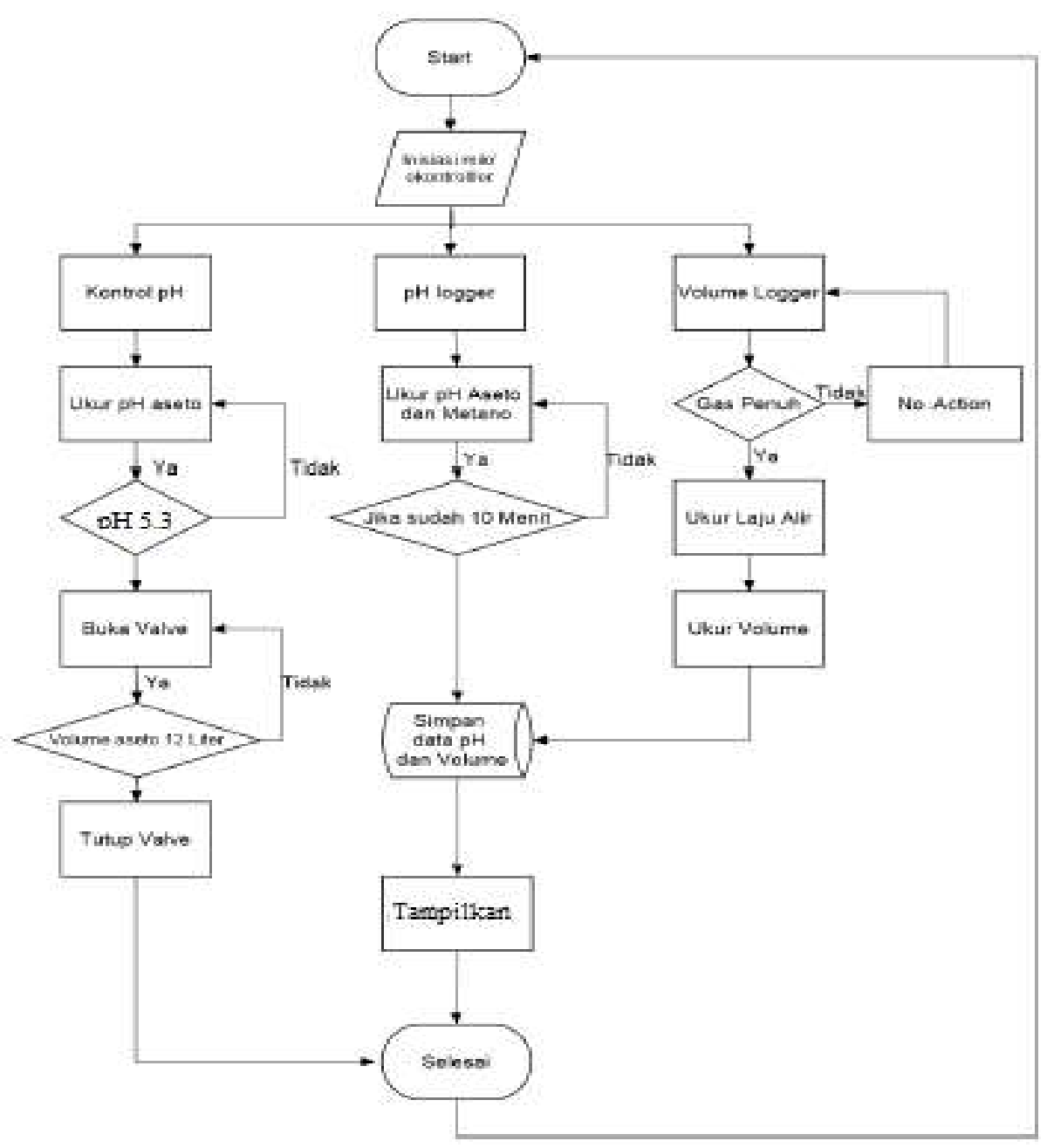

Gambar 6. Diagram Alir Sistem Monitoring dan Kontrol Biodigester Dua Tahap 
Masukan berupa $\mathrm{pH}$ digunakan sebagai penentu apakah valve dari digester asetogenesis menuju metanogenesis akan dibuka atau tidak. Selama proses penentuan itu dilakukan terjadi recording data yang terbaca oleh sistem. Flowmeter memberikan informasi berapa jumlah volume gas yang sudah dihasilkan selama proses fermentasi berlangsung.

Dengan flowchart pada Gambar 6, sistem direalisasikan dengan pemasangan sistem kontrol pada plant biogas dua tahap. Gambar 7 menunjukkan biodigester dua tahap yang telah direalisasikan dan telah terpasang sistem kontrol yang diusulkan.

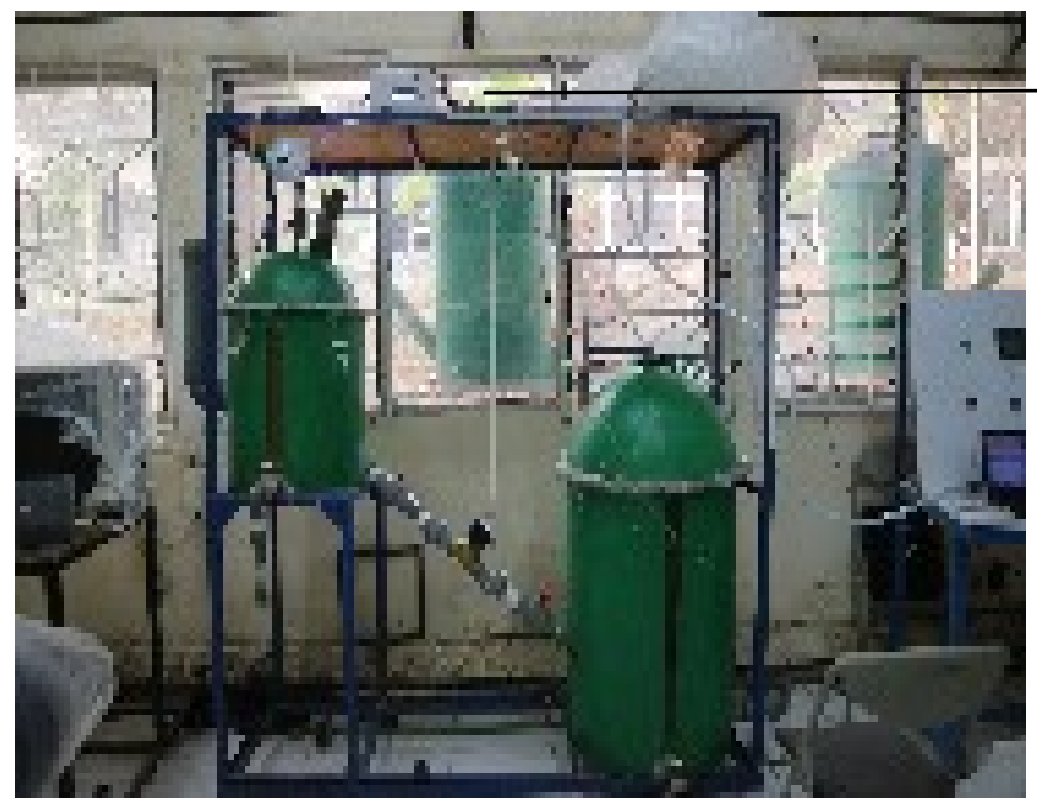

(a) Plant Biogas

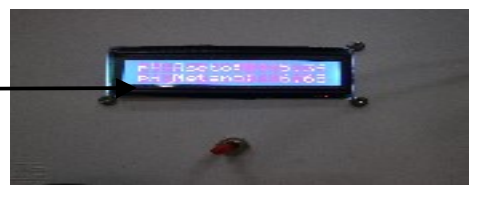

(b) monitoring $\mathrm{pH}$

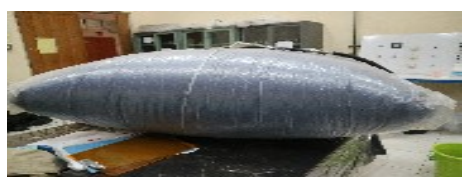

(c)penampung gas

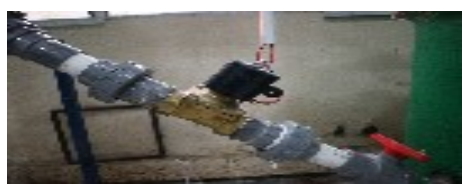

(d)solenoid valve

\section{Gambar 7. Biodigester Dua Tahap Dengan dengan Sistem Kontrol yang Diusulkan}

Gambar 7 terdiri dari dua buah digester, digester asetogenesis dan digester metanogenesis (a). Data monitoring ditampilkan dengan LCD (b) yang menunjukkan nilai pH terbaca pada digester asetogenesis dan metanogenesis. Selain itu data volume gas yang dihasilkan untuk ditampilkan dan hasilnya ditampung pada penampung (c). Jika nilai set point yang ditentukan sudah tercapai, solenoid valve akan membuka dan mengalirkan limbah dari digester asetogenesis menuju digester metanogenesis (d).

\section{HASIL DAN PEMBAHASAN}

Pengujian dilakukan pada digester asetogenesis dan metanogenesis yang berisi fluida limbah tahu yang dikombinasi dengan kotoran sapi sebagai starter-nya. Sensor pH diletakkan pada digester asetogenesis dan digester metanogenesis untuk mengetahui perubahan nilainya. Perubahan nilai $\mathrm{pH}$ pada digester asetogenesis sesuai dengan set point yang ditentukan akan menyebabkan valve akan terbuka secara otomatis yang akan menyebabkan dialirkannya limbah yang berada pada digester asetogenesis menuju digester metanogenesis. Dalam digester metanogenesis, limbah ini akan mengalami proses selanjutnya untuk menghasilkan gas metan. Dengan berpindahnya limbah dari digester asetogenesis menuju digester metanogenesis menunjukkan bahwa digester asetogenesis siap untuk diisi limbah yang baru sebagai bahan baku penghasil gas metan. Kontinuitas pengisian diharapkan dapat menekan 
terputusnya pengisian bahan baku yang dapat mengakibatkan terjadi diskontinuitasnya biogas yang dihasilkan.

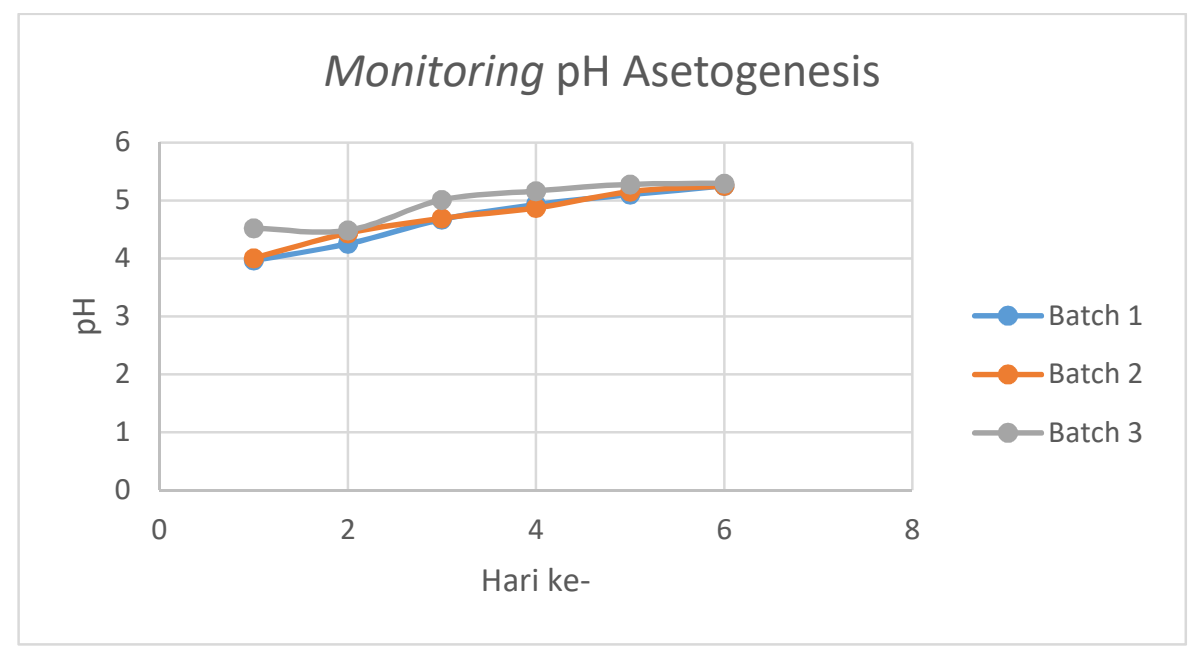

Gambar 8. Pengujian pH Digester Asetogenesis

Pengujian monitoring $\mathrm{pH}$ pada digester asetogenesis dilakukan tiga batch dengan menggunakan set point pH sebesar 5.3 (Gambar 8). Nilai set point pH dapat tercapai pada hari ke enam untuk ketiga batch. Untuk digester metanogenesis, nilai set point pH yang digunakan adalah 7 dengan nilai toleransi $\pm 0,3$ sesuai dengan rentang yang diperbolehkan untuk menghasilkan biogas. Kondisi ini dapat dijaga seperti yang diilustrasikan oleh Gambar 9 dengan melakukan tiga kali pengujian. Gambar 9 ini menunjukkan bahwa proses pembentukan gas metan dapat berjalan sesuai dengan $\mathrm{pH}$ yang dapat ditoleransi.

Jika nilai $\mathrm{pH}$ pada digester metanogenesis tidak sesuai dengan set point yang ditentukan (terbaca dari nilai yang ditampilkan oleh LCD), maka perlu dilakukan proses pengadukan oleh operator untuk dapat mengubah nilai $\mathrm{pH}$ agar mencapai set point.

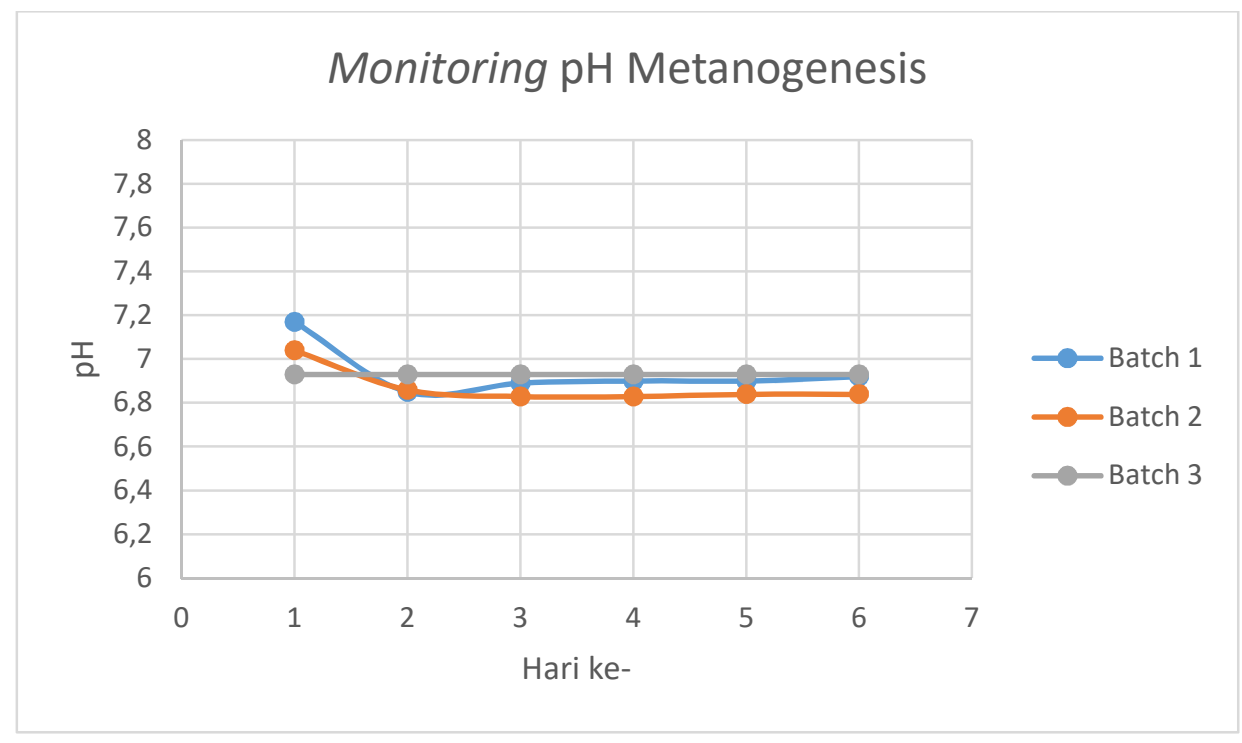

Gambar 9. Pengujian pH Digester Metanogenesis

Pengukuran volume gas yang dihasilkan merupakan salah satu parameter yang dapat menunjukkan berapa banyak biogas yang diproduksi selama proses fermentasi (Gambar 10). Pengukuran ini berada pada keluaran digester metanogenesis dan dilakukan dengan proses 
penampungan biogas yang dihasilkan kemudian dilakukan pengukuran volume biogas yang diproduksi.

Pengukuran volume biogas ini dilakukan sensor flow YF-S201 yang dapat mengubah besaran aliran fluida udara menjadi PWM (Pulse Width Modulation) yang hasilkan dari putaran yang terjadi akibat dari aliran fluida. PWM yang dihasilkan diterjemahkan oleh mikrokontroller menjadi besaran flow per-satuan waktu dan dikonversi menjadi satuan volume menggunakan Persamaan (1). Sehingga dapat terbaca volume gas yang dihasilkan selama proses fermentasi.

Melalui proses monitoring terlihat bahwa produksi biogas siap dipanen pada hari ke dua (bahan baku berada pada digester metanogenesis pada hari kedua). Volume biogas tertinggi yang dihasilkan pada batch pertama sejumlah 32.5 L. Sedangkan pada batch ke dua dan ketiga volume tertinggi berada pada $38.2 \mathrm{~L}$ dan $42.3 \mathrm{~L}$. Produksi biogas selanjutnya mengalami penurunan sesuai dengan berkurangnya ketersediaan jumlah nutrisi bagi bakteri seiring dengan sudah dihasilkannya biogas dari hari sebelumnya. Volume biogas yang dihasilkan ini relatif stabil sampai pada data pengujian hari terakhir. Pemanenan biogas dapat dilakukan sepanjang sensor volume menunjukkan terbacanya biogas yang diproduksi. Kontinuitas produksi dapat terjaga jika terdapat bahan baku di dalam digester metanogenesis yang berasal dari digester asetogenesis.

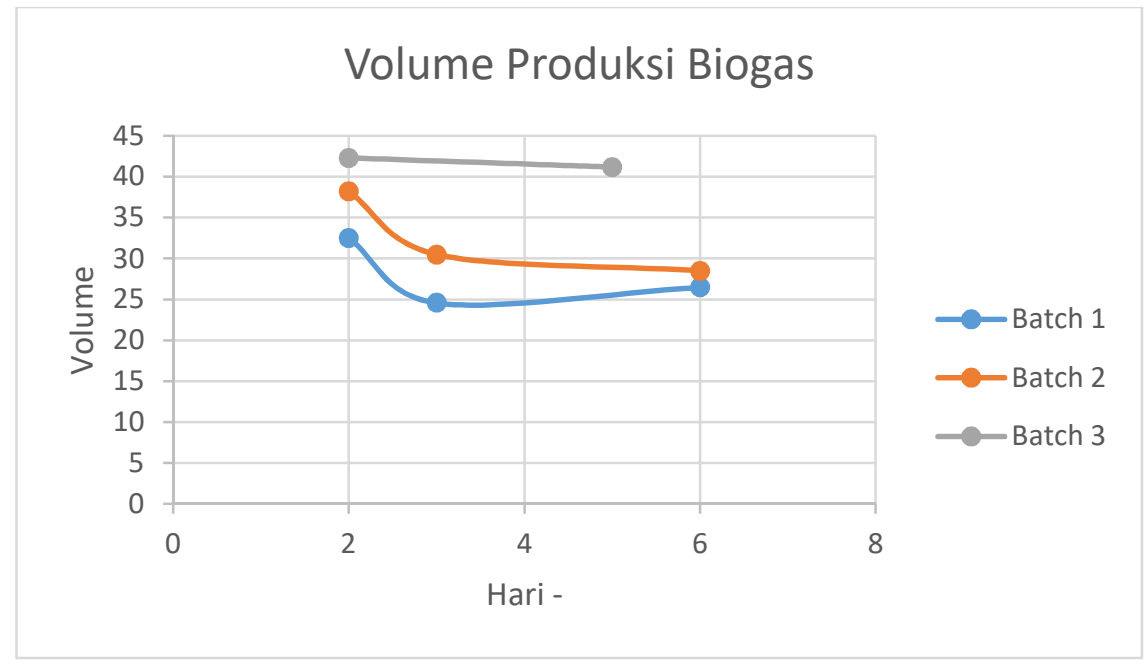

Gambar 10. Monitoring Jumlah Produksi Biogas

\section{KESIMPULAN}

Digestasi anaerobik merupakan proses kompleks dan sensitif yang terjadi dalam biodigester dan merupakan proses sensitif yang dapat merubah kondisi lingkungan ke arah yang lebih baik. Pengetahuan mengenai karakteristik proses tersebut sangat krusial untuk mendapatkan pengoperasian yang sesuai serta untuk mendiagnosis dan memecahkan permasalahan yang timbul selama proses fermentasi berlangsung. Monitoring dan pengendalian proses biodigester merupakan salah satu solusi yang dibutuhkan untuk meningkatkan performansi dan jumlah biogas yang dihasilkan. Hasil pengujian biodigester dua tahap menggunakan sistem monitoring dan kontrol yang diausulkan menunjukkan bahwa sistem dapat secara kontinyu memantau parameter $\mathrm{pH}$ yang dibutuhkan dalam proses pembentukan biogas serta memberikan informasi jumlah biogas yang dihasilkan selama proses berlangsung. Sistem yang diajukan juga memberikan bukaan katup otomatis dari digester asetogenesis menuju digester metanogenesis jika kondisi nilai set point $\mathrm{pH}$ yang diberikan sudah tercapai. Informasi volume 
biogas yang dihasilkan (dalam liter) dapat memudahkan untuk mengetahui jumlah biogas yang dihasilkan serta menentukan berapa jumlah penampung yang dibutuhkan. Sistem ini sangat sesuai digunakan untuk jenis limbah yang berbeda dengan melakukan penyesuaian sesuai dengan kondisi yang dibutuhkan.

\section{UCAPAN TERIMA KASIH}

Ucapan terima kasih disampaikan kepada Kemenristekdikti yang telah mendanai penelitian Stranas (Strategis Nasional) ini periode 2017-2018.

\section{DAFTAR RUJUKAN}

Ahmed, W. A., Aggour, M., \& Bennani, F. (2015). Smart System for Bio Digester Monitoring. 3rd International Renewable and Sustainable Energy Conference (IRSEC), (pp. 1-4)

Angelidaki, I., \& Ahring, B. K. (1997). Co-digestion of olive oil mill wastewaters with manure, household waste or sewage sludge. Biodegradation, 8, 6 .

Batstone, D. J., Keller, J., \& Blackall, L. L. (2004). The influence of substrate kinetics on the microbial community structure in granular anaerobic biomass. Water Research, 38, 15.

Boe, K. (2006). Online monitoring and Control of the Biogas Process: Lyngby. Technical University of Denmark.

Dedgaonkar, S., Mohire, A., Jadhav, A., Pawar, S., \& Bane, R. (2016). Biogas Monitoring System for Measuring Volume using Micro-controller \& GSM. International Journal of Current Engineering and Technology, 6(5), $1553-1557$.

Demirtas, M., Sefa, I., Irmak, E., \& Colak, I. (2008). Low-Cost and High Sensitive Microcontroller Based Data Acquisition System for Renewable Energy Sources. Paper presented at the International Symposium on Power Electronics, Electrical Drives, Automation and Motion.

Iriani, Purwinda., Utami, Sri., dan Y. Suprianti. (2018). Biomethanation of Tofu Liquid Waste Using Two-stage Anaerobic Fermentation System. American Institute of Physics (AIP) Conference Proceedings. 2021, 020005-1 - 020005-7

Juangga, A. (2007). Biogas untuk Masa Depan Pengganti BBM. Jurnal Ilmiah, $4: 25$.

Karoly, R., \& Dumitru, C. D. (2014). The Monitoring and Control Processes of a Renewable Energy Management System. Paper presented at the 8th International Conference Interdisciplinarity in Engineering, Romania.

Labatut, A. R. (2009). The Effect pH on Digester Multi Stage. Cambriddge university. 
Maheshwari, O., Ramesh, S. M., Arasi, M. M., \& Priya, C. L. (2014). Wind Turbine Measurement System Using Microcontroller As Data Acquisition. International Journal of Advanced Research in Electronics and Communication Engineering (IJARECE), 3(10), 2.

Muljatiningrum, \& Sukmana, R. (2011). Biogas dari Limbah Ternak. Bandung Penerbit Nuansa. Soetopo, R. S., Purwati, S., Idiyanti, T., Wardhana, K. A., \& Aini, M. N. (2010). Produksi Biogas Sebagai Hasil Pengolahan Limbah Lumpur Industri Kertas dengan Proses Digestasi Anaerobik Dua Tahap. Riset Industri Kemenperin.

Sunil, M., Narayan, A., Bhat, V., \& Vinay, S. (2013). Smart Biogas Plant. International Journal of Innovative Technology and Exploring Engineering (IJITEE), 3(3), 62-66.

Switzenbaum, M. S., Giraldo-Gomez, E., \& Hickey, R. F. (1990). Monitoring of the anaerobic methane fermentation process. Enzyme and Microbial Technology, 12, 8.

Trisna, A. (2015). Rancang Bangun Teknologi Pemurni Air. Universitas Negeri Jember.

Utami, S., Saodah, S., \& Pudin, A. (2018). Penggunaan Algoritma Incremental Conductance pada MPPT dengan Buck Converter untuk Pengujian Indoor dan Outdoor. Elkomika, 6(1), 97- 109. 